DOI 10.18551/rjoas.2019-07.21

\title{
CORPORATE CITIZENSHIP IMPLEMENTATION AT PT UNITED TRACTORS, TBK: A SYSTEMATIC REVIEW
}

\author{
Erfianto Wawan*, Mulyati Heti, Suprayitno Gendut \\ Program of Management Science, Postgraduate School, IPB University, Bogor, Indonesia \\ *E-mail: wawanerf@gmail.com
}

\begin{abstract}
Corporate Citizenship measures four dimensions namely economic, legal, ethical and philanthropic which have strategic values and have a positive impact on the company. PT United Tractors, Tbk implements good corporate governance (GCG) as an effort to improve the performance of a company. GCG is part of the roadmap towards Corporate Citizenship so that its implementation is reviewed based on four dimensions. The economic dimension, that is, the company has an economic function proven by the company experiencing growth in the assets, income and profits of the company. The implementation of the law shows that the company integrates legal compliance into the company's strategy, this shows the implementation of the legal dimension. The implementation of the management system in the company is part of the implemented ethical dimension. For the dimension of philanthropy can be seen from companies that use the AGC and AFC guidelines to guide them to become environmentally friendly and social responsible companies managed under the Public Contribution Roadmap framework. After knowing the implementation of Corporate Citizenship in the company, the next step is to quantitatively measure its implementation and the influence that has been given to the company.
\end{abstract}

\section{KEY WORDS}

Corporate citizenship, economics, legal, ethical, philanthropy.

Corporate Citizenship is a core element of business strategy in meeting economic, social, and political demands and to enhance the role of the company in the decision making process, with three strategic value points namely market benefits in differentiation and cost reduction, anticipating constraints and preventing risks and meeting environmental needs (Eberhard, 2011). As legal entities with rights and duties such as citizens of the countries in which they operate (Matten, 2003), companies establish Corporate Citizenship with a leadership foundation at all levels, employee engagement, measured financial systems and public-private partnerships (Economist Intelligence Unit, 2008). According to Carrol, 1998 the Corporate Citizenship is a derivative of the conceptualization of the role of business in society in the management literature, where the most dominant derivative is dominated by the idea of CSR (Corporate Social Responsibility) which measures four dimensions:

- Economy, which is profitable (fulfilling the company's economic responsibilities);

- Legal, which is obedient to the rule of law (fulfilling corporate legal responsibilities);

- Ethics, which is ethical behavior (response to the company's ethical responsibilities);

- Philanthropy, which is to contribute to giving back to the environment what has been received.

The impact of Corporate Citizenship on the company can be positive for several things, namely reputation management, profile and risk management, recruitment, motivation and employee retention rates, investor relations and access to capital, learning and innovation, competitiveness and market position, efficient operations and operating permit (Little, 2003). With this positive value, a review is needed to determine the implementation of Corporate Citizenship in companies based on literature as secondary data owned by the company. 


\section{METHODS OF RESEARCH}

This research methodology uses a systematic review method by taking qualitative data collected from secondary data for research purposes. The stages in systematic review consist of identification review, initial article screening, advanced article screening and article evaluation (Fitroh \& Utama, 2017). The results of systematic review of this review and packaging of research results into actionable messages (policy brief and policy paper) are comprehensive and balanced facts presentation formats for policy makers (Siswanto, 2010). This research was conducted to answer the implementation of Corporate Citizenship at PT United Tractors, Tbk.

\section{RESULTS AND DISCUSSION}

PT United Tractors, Tbk (United Tractors) is a company listed on the Indonesia Stock Exchange, whose shares are owned by the public $40.5 \%$ and owned by PT Astra International 59.5\% established since 1972 with the main business being trading tools heavy in the construction sector with the brands Komatsu, Scania, UD Truck, Tadano and Bomag (UT Annual Report, 2017). As a trading company, in addition to selling products, United Tractors also provides after-sales services, namely sales of spare parts and repair services with major customers, namely companies engaged in the mining, agriculture, forestry, construction and transportation sectors. In its activities, United Tractors implements good corporate governance (GCG) and implements corporate social responsibility (CSR). Good Corporate Governance (GCG) as an effort to improve the performance of a company / organization and become a guideline for company leaders in making decisions and carrying out actions based on high morals, compliance with applicable laws and regulations and awareness of social responsibility the company to stakeholders (stakeholders) consistently. What is done is a Roadmap that starts from good corporate governance (GCG) that is fulfilling the provisions of regulations in corporate governance to be a good corporate company that can effectively control business operations, especially business risk aspects, to become good corporate citizens namely industrial citizens and social communities. ethical and responsible.

The economic dimension of Corporate Citizenship, namely the view of the economy as a good individual citizen is that he can support himself and is not a burden on other parties, where the company's economic responsibility is to generate profits in a way that is not contradicting good corporate citizenship. Therefore as a form of participation in society and being a good citizen, companies work to generate sufficient income to pay costs and share profits with investors for their investments and other stakeholders guaranteed business continuity, product flow, services, jobs, and other benefits provided by the company (Carrol, 1998). In accordance with UT Annual Report, 2017, the company economically experiences growth in assets, revenues and profits of the company with several parameters, where in 2017 the company experienced a $29 \%$ increase in assets to Rp 82.3 trillion, net income rose $48 \%$ to $\mathrm{Rp} 7.4$ trillion, market capitalization reaches $\mathrm{Rp} 132$ trillion. Besides being a public company that shares its profits with shareholders, in 2017 the profits distributed per share

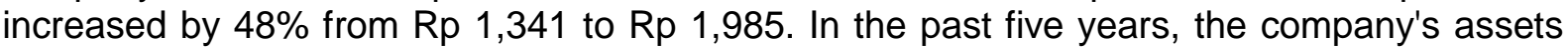
have grown annually from Rp. 57.4 trillion in 2013 to Rp. 82.3 trillion in 2017.

The legal dimension of good Corporate Citizenship, such as the person, also obeys the law by seeing it as codified ethics (which is recorded as a rule), so that when business ethics are all right, good and fair for business, the law is made to realize standards - these standards are in business performance, so that to create them legislation is designed to regulate relationships with key stakeholders such as customers, employees, society and the environment. If the business wants to be considered and admired as good corporate citizenship, it must comply with these laws and integrate legal compliance into its corporate strategy and operational management (Carrol, 1998). The legal dimension of Corporate Citizenship is in line with the principles of GCG, where the World Bank defines GCG is a collection of laws, regulations and rules that must be fulfilled that can drive the performance 
of company resources to work efficiently, generate sustainable long-term economic value for shareholders and the surrounding community as a whole (Iskander and Chamlou, 2000). United Tractors' commitment to law is manifested by the company with an internal control system that includes financial risk, effectiveness of operational activities, and compliance with applicable laws and regulations (UT Annual Report, 2017). The implementation of Good Corporate Governance (GCG) is in line with applicable regulations including the Law of the Republic of Indonesia No. 40 of 2007 concerning Limited Liability Companies ("Law No. 40/2007") and Law of the Republic of Indonesia No. 8 of 1995 concerning Capital Markets (UT Annual Report, 2017). Management of employees in the company refers to the Law of the Republic of Indonesia No. 13 of 2003 concerning employment and derivative rules. The company's health and safety system is based on the Law of the Republic of Indonesia No. 1 of 1970 concerning work safety with the aim of managing the K3 aspect is the achievement of a zero lost time injury (Zero LTI) condition in all operational areas with one of the reference performance indicators being a measure of frequency rate (FR) and severity of work accidents/severity rate (SR).

The ethical dimension of Corporate Citizenship views that exemplary businesses not only have value because they are economically successful and comply with the law, but try to run it ethically. When the legal dimension refers to "minimum" behavior, a norm is needed to discuss social problems that can arise. Business ethics related to concepts and practices of acceptable business behavior in interacting with various stakeholders, an important aspect of business ethics is "knowing ethics" and "doing ethics" (Carrol, 1998). Good corporate citizenship will distinguish two moral philosophies, namely descriptive ethics related to describing organizational behavior (what is being done) and normative ethics relating to the provision and justification of an appropriate moral system (what must be done), so it needs to be more interested in what should be done than what is being done. Virtuous citizens, both personal and corporate, will also be virtuous in their actions, decisions and practices. Good corporate citizenship requires companies and managers to lead with strong ethical values and implement them and in accordance with the law and display ethical leadership in the community by using good ethical principles or character to bring about right and fair behavior and actions so that the organization strives for ethical excellence to be able to ensure they have a solid future (Carrol, 1998). Implementation of management systems is a series of activities (cycles) that are sustainable from the organization to achieve goals in accordance with the wishes of stakeholders. To ensure the implementation of a standard management system in the company, an audit system is carried out periodically, one of which is ethics. The ISO portfolio provides practical tools for all three dimensions of sustainable development, namely economic, environmental and social. In its implementation due to violations of this management system, for example a company performing poor environmental performance can cause customers to boycott products and services, with the consequence of financial loss. In extreme cases, the general public can also take direct action that is blocking or even stopping company operations (Morris, 2004). To continue to maintain and improve the Information Technology Governance standard at United Tractors, the Corporate Strategic and Technology (CST) division applies ISO 20000: 2011 (Information Technology Management Services) and 27001: 2013 (Information Security Management System). The Risk Management System implemented since 2006 and refers to ISO 31000 and the Astra Risk Management Framework. In CSR practice the company applies ISO 9001: 2008, ISO 14001: 2004, OHSAS 18001: 2007, Occupational Health and Safety Management System (SMK3) according to PP No. 50/2012, and the PROPER standard (Corporate Performance Rating Program) in accordance with Minister of Environment Regulation No. 3/2014. A series of company internal policies related to GCG include the whistleblowing system. In implementing the internal control system, the company adopted the Standard IIA (Institute of Internal Auditors) and the COSO Framework. The company also uses the Astra Green Company (AGC) and Astra Friendly Company (AFC) guidelines to guide initiatives to become environmentally friendly and socially responsible companies. Contractor Safety Management System (CSMS) This system manages the performance of 
contractors in the Company's managed area, starting from the planning stage to the implementation stage.

Philanthropy is the desire to help humanity through charitable actions, whether carried out by private citizens, foundations, or companies that aim to improve the quality of life and to ensure a better future, where philanthropy is realized through corporate contributions known as a general definition from Corporate Citizenship (Carrol, 1998). This is inspired by the desire to improve life for others while at the same time improving life for oneself. Corporate citizenship is growing rapidly with a variety of popular initiatives, such as financing education for employees, promoting ethical training programs, supporting environmentally friendly policies and sponsoring community events (Maignan and Ferrell, 2000). According to Moon Jeremi et al., 2005, Corporate citizenship is used to underline, expand or reorient certain aspects of CSR (Corporate Social Responsibility). The Astra Friendly Company (AFC) guideline provides the basis for meeting stakeholder expectations and implementing effective CSR initiatives. Stakeholders encourage companies to schedule social responsibility (CSR) when they formulate corporate citizenship policies to trigger companies to invest in social innovation and environmental responsibility (Camilleri, 2017). One of the company's missions is to generate sustainable added value for stakeholders through three balanced aspects in terms of economic, social and environmental aspects. United Tractors' core values were formed to reflect the philosophy of Catur Dharma which is the foundation of the Astra Group, which invites all employees to become beneficial property for the nation and state, provide the best service to customers, respect individuals and foster cooperation, and always strive to achieve best. The company uses the Astra Green Company (AGC) and Astra Friendly Company (AFC) guidelines that guide initiatives to become environmentally friendly and socially responsible companies, which are managed under the Public Contribution Roadmap framework. Public Contribution Roadmap begins with Creating an environmentally friendly company, then builds a harmonious relationship with the community and actively participates in community economic empowerment programs so that at the end it organizes CSR initiatives to improve people's quality of life, especially in the aspects of education and health. Astra Green Company (AGC) guides the implementation of Environmental Safety and Health initiatives to achieve 4 (four) target pillars, namely:

- Green Strategy that all aspects of the Environment, Occupational Safety and Health have become part of the strategy and business activities;

- Green Process that all processes and procedures are in accordance with Environment, Occupational Safety and Health regulations and standards both at national and international levels;

- Green Product that products and services are safe and environmentally friendly;

- Green Employees that Environment, Occupational Safety and Health integration in daily work by employees and related parties, through the provision of training and implementation of events that can improve Environment, Occupational Safety and Health awareness.

\section{CONCLUSION AND SUGGESTIONS}

In line with the vision of becoming global corporate citizenship, the company is fully committed to harmonizing business performance with the provision of benefits to society and the environment as part of corporate stakeholders carried out through the implementation of Corporate Social Responsibility (CSR) programs, with the aim of balancing economic performance achievement social aspects and aspects of environmental sustainability, namely to carry out the concept of triple bottom line (Portfolio, People, and Public Contribution Roadmap) in total (UT Annual Report, 2017). Based on secondary data from the company's annual report, it appears that the company has implemented corporate citizenship in four dimensions, both economic dimensions, legal dimensions, ethical dimensions and philanthropic dimensions. Implementation in the economic dimension, it can be seen that the company has an economic function that is generating enough income to pay for operational costs and share profits to investors as evidenced by the company experiencing growth in the 
company's assets, income and profits. For the legal dimension, that is, complying with the company complies with laws and regulations and integrating legal compliance into the company's strategy and operational management, it can be seen that there is a legal basis that is obeyed and carried out in accordance with the state-regulated field. The application of the management system in the company including the application of ISO is part of the implemented ethical dimension. From the dimension of philanthropy, the implementation can be seen from companies that use the AGC and AFC guidelines to guide them to become environmentally friendly and socially responsible companies to achieve the company's mission of generating sustainable added value for stakeholders through three balanced aspects in economic terms, social and environment.

Having known the implementation of Corporate Citizenship, as written by Morrison et al., 2007 that companies choose corporate citizenship as a useful tool not only to improve the reputation of the public, but also to increase employee engagement. In accordance with the company's goal that it wants to be good corporate citizenship, but it has never been evaluated as to the extent of its achievement so that it is necessary to quantitatively measure its implementation and the influence given to the company. If this is done, it is hoped that workers will know their role in building corporate citizenship in the company so that they will make a positive contribution and the company knows the extent of the influence of corporate citizenship on the management of the company so that efforts are made to have a positive impact on it.

\section{REFERENCES}

1. Camilleri Mark Anthony. 2017. Corporate Citizenship and Social Responsibility Policies in America. Sustainability Accounting, Management and Policy Journal. No 8 (1):1-34.

2. Carrol Archie B. 1998. The Four Faces of Corporate Citizenship. Business and Society Review. Volume 100(101):1-7. Published by Blackwell Publisher.

3. Eberhard H Laurence. 2011. Strategic Value of Corporate Citizenship: Theory and Practice of Corporate Social Responsibility. Talence (France). Springer.

4. Economist Intelligence Unit. 2008. Corporate Citizenship : Profiting from a sustainable business. The Economist.

5. Fitroh, Utama, D.N. 2017. Synthesizing a Soft System Methodology Use in Information Systems Research Field: A Systematic Review. 2017 Fifth International Conference on Information and Communication Technology (ICoICT) : 489-492. Kuala Lumpur.

6. Iskander Magdi R and Chamlou Nadereh. 2000. Corporate Governance: A Framework for Implementation. Washington, D.C. (USA). The World Bank.

7. Little A.D. 2003. The Business Case For Corporate Citizenship. Word Economic Forum.

8. Maignan I and O C Ferrell. 2000. Measuring Corporate Citizenship in Two Countries: The Case of the United States and France. Journal of Business Ethics. No 23(3):283-297. DOI : 10.1023/A:1006262325211.

9. Matten D, Crane A. 2003. Corporate Citizenship: Towards an extended theoretical conceptualization. International Centre for Corporate Social Responsibility. No 3-2003:121:429-453. ISSN 1479-5116.

10. Moon J, Crane A, Matten D. 2005. Can corporations be citizens? Business Ethics Quarterly. Volume 15 (3):429-453. ISSN 1052-150X.

11. Morris Allan S. 2004. ISO 14000 Environmental Management Standards: Engineering and Financial Aspects. West Sussex (England). John Wiley \& Sons, Ltd.

12. Morrison E E, G C Burke III and L Greene. 2007. Meaning in Motivation: Does Your Organization Need an Inner Life?. Journal of Health and Human Services Administration. No 30(1): 98-115. http://ecommons.txstate.edu/sohafacp/1.

13. Siswanto. 2010. Systematic Review as a Research Method for Synthesizing Research Results (An Introduction). Surabaya. Pusat Penelitian dan Pengembangan Sistem dan Kebijakan Kesehatan, Badan Litbang Kesehatan, Kementerian Kesehatan.

14. United Tractors. 2018. Annual Report 2017 : Delivering Togetherness. Jakarta (ID). PT United Tractors, Tbk. 